\title{
МЕДИАТЕКСТЫ ПОЛИТИЧЕСКОГО ДИСКУРСА КИТАЯ В УСЛОВИЯХ УКРАИНСКОГО КРИЗИСА: ОПЫТ СОПОСТАВИТЕЛЬНОГО И ДИСКУРСИВНОГО АНАЛИЗА
}

\begin{abstract}
Аннотация: В данной статье рассматривается проблема инструментария прикладньх политлингвистических исследований. Основной тезис: лингвистическое знание - один из эффективных инструментов прикладных политологических исследований. Автор делает попытку рассмотреть и проанализировать китайские новостные тексты по конкретной кризисной ситуации как жанровую разновидность медиатекстов Китая (с российской территории) на предмет выявления информационно-коммуникативных технологий. Медиадискурс в руках политиков выступает мощным ресурсом, используемым для формирования общественного мнения, для завоевания поддержки населения. Методологическую основу исследования составляют системньй, структурно-функциональный, сравнительно-исторический, сравнительно-политический, геополитический и культурно-иивилизационный подходы, методы анализа, синтеза, индукиии, дедукиии, моделирования, наблюдения. Важным условием достижения политического успеха является продуманность выбора языка общения с массовой аудиторией, которое осуществляется с помощью средств массовой инбормации и коммуникаиии. Увеличение роли языка в общественной жизни приводит к повышению уровня сознательного вмешательства в языковые практики с помощью специальных технологий.
\end{abstract}

Ключевые слова: Политика, управление, китайские «новые медиа», информационная война, политлингвистика, медиатекст, политический дискурс, информационное противоборство, перевод, безопасность

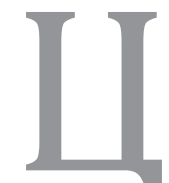

елью статьи является анализ медиатекстов политического дискурса КНР в кризисной ситуации на Украине с точки выявления позиции КНР в информационной войне.

В современной мировой науке, развивающейся по пути междисциплинарности, характерна ситуация при которой разработки в сфере естественных наук и цифровых технологий начали оказывать влияние на гуманитарное знание и, наоборот. Эффекты массовой коммуникации наиболее полно проявляются в сфере информирования: из сообщений СМИ аудитория получает информацию об относительной значимости события. Поэтому возможность влияния на познавательные способности аудитории является одной из важнейших составляющих власти массмедиа.

Язык средств массовой информации - живая и динамичная субстанция, особенно чувствительная к новым идеологическим веяниям, духовным переменам и модным тенденциям в той или иной общественной структуре. «Именно в языке СМИ, как сквозь прозрачное увеличительное стекло, можно наблюдать обновление и модернизацию традиций, интерпретацию концептуальных моделей национального мировидения относительно конкретного историко-социального бытия общества» ${ }^{1}$. Языковые средства медиатекстов образуют совокупность знаний об объекте и собственно субъекте в упорядоченной системе утверждений. Для каждого утверждения дискурса строится своя ментальная модель. Каждое новое утверждение добавляет новые сущности, свойства и отношения ${ }^{2}$.

Возрастающая роль КНР как глобального игрока на мировой арене очевидна. Благодаря бурному экономическому росту у современного Китая появляется все больше ресурсов для решения своих геополитических и экономических интересов далеко за пределами АТР. Широкому кругу проблем международного сотрудничества КНР, понятийного аппарата политологического

\footnotetext{
${ }^{1}$ Ерофеева И.В. Язык современных СМИ: к проблеме миромоделирования // Гуманитарный вектор. - 2012.- №4 (32). - C. $34 .-41$.

${ }^{2}$ Екшембеева Л.В. Прикладные исследования в контексте новых качеств лингвистического знания. [Электронный реcypc]. - URL: http://gisap.eu/ru/node/28927 (дата обращения 29.12.2013).
} 


\section{Тренды и управление 3(7) • 2014}

осмысления процессов внешнеполитической деятельности Китая, вопросов обеспечения национальной безопасности и стратегического планирования и других смежных проблем посвящены труды известных российских ученых, таких как: У. И. Берзиня, М. Л. Титаренко, Н. А. Спешнев, А. П. Девятов, С. Г. Лузянин, А. Н. Алексахин, А. М. Байчоров, В.Я. Портяков, А.Н. Карнеев, Ю.М. Галенович, Д. В. Кузнецов, Н. В. Кухаренко, С. В. Кухаренко, О. А. Шеломихин, Я. М. Бергер, К. С. Ануфриев, К. П. Боришполец, А. А. Волохова, В. В. Кочетков, а также работы зарубежных ученых, таких как: Ф. Бергстен, Бэйтс Гилл, Николас Ларди, Дерек Митчелл. Внешнеполитические и внешнеэкономические приоритеты лежат сегодня в трех плоскостях: во взаимоотношениях со странамисоседями; в Азиатско-тихоокеанском регионе; в рамках осуществления глобальной политики ${ }^{3}$. В своей внешней политике Китай стремится решить несколько задач: создать мирную международную среду, в которой он сможет продолжать свое экономическое развитие и в которой можно представить себя в качестве ответственного и конструктивного игрока; обеспечить ресурсы, необходимые для поддержания своего экономического развития; создать международные политические альянсы, которые разделяют отрицательную китайскую позицию к внешнему вмешательству во внутренние дела других государств; убедить других, что он является великой державой, возможно, способной стать вровень с США, и воссоединить материковый Китай с Тайванем по апробированной в Гонконге и Макао модели. Так, геостратегия США и Китая противоречат друг другу по тайваньскому вопросу и далее по островам в Восточно-Китайском и Южно-Китайским морям. Определение позиции по Крыму стало особенно сложным для Китая, т.к. в данной ситуации политика России по отношению к Крыму может создать нежелательный для Китая прецедент и стать в самом Китае источником немалых проблем в будущем: ситуация, когда регион, формально являющийся административной единицей страны, проводит референдум и по его результатам объявляет себя независимым, может для китайских властей стать источником

\footnotetext{
${ }^{3}$ Байчоров А. М. Китаизация: последствия роста мощи Китая для мира в XXI веке. М.: Международные отношения, 2013. С. 100.
}

беспокойства в Синьцзяне и Тибете. Однако Китай и Россию сближает общая озабоченность планами США экспортировать под флагом демократии технологии «цветных революций»: «для Китая на первом месте сейчас стоят задачи борьбы с «исламским» экстремизмом, несущим угрозу стабильности и территориальной целостности Северо-Западного Китая» ${ }^{4}$.

Европа и США рассматривают Китай каквызов. Китайская альтернативная модель развития для развивающихся стран может «затмить» западную модель, основанную на либеральной демократии и рыночной экономике. По мнению европейцев, глобальное влияние Китая становится все менее благоприятным. Россия и Китай остро осознают, что в этих условиях необходимо формирование альтернативных центров силы, которые являлись бы сдерживающим фактором для США. Россия, Китай, а также страны БРИКС, укрепляющие свои позиции на международной арене, постепенно становятся такими центрами силы. Ученые-гуманитарии, несомненно, в перспективе будут «выделять состоявшуюся 16-17 июля в бразильском городе Форталеза встречу глав государств, входящих в группу БРИКС, как один из поворотных моментов истории, сравнимый с поражением Наполеона под Ватерлоо в 1815 году, и подъемом британского, а затем и американского имперского доминирования в мире. Очевидно, что Владимир Путин играет ведущую роль в создании исторической альтернативы англо-американской монетарной и финансовой системе в лице БРИКС. ... Безусловно, самым важным соглашением, достигнутым на встрече, стало соглашение о создании так называемого Нового банка развития с первоначальным капиталом 50 миллиардов долларов, который впоследствии может быть увеличен до 100 миллиардов» ${ }^{5}$. Такое «масштабное продвижение Китая в Латинской Америке не могло не вызвать ревнивой реакции в Соединенных Штатах» ${ }^{6}$ Соответственно, на гео-

\footnotetext{
${ }^{4}$ Титаренко М.Л. Россия и ее азиатские партнеры в глобализирующемся мире. Стратегическое сотрудничество: проблемы и перспективы. - М.: ИД «ФОРУМ», 2012. - С. 407.

${ }^{5}$ Энгдаль Уильям. Альтернатива, с которой придется считаться. [Электронный ресурc]. - URL: http://www. rg.ru/2014/07/23/engdal.html (дата обращения 28.06.2014).

${ }^{6}$ БРИКС - Латинская Америка: позиционирование и взаимодействие (под. общ. ред. В. М. Давыдова). - М.: ИЛА РAH, 2014. C. 78.
} 
стратегической карте мира, границы которого больше определяются общими идеологическими концепциями, доктринами и моделями поведения возникает некоторая опасность смены американизации, например, китаизацией, русинизацией и т.д. В эволюции международных конфликтов возникла новая фаза - межцивилизационная.

Очевидно, что вся цепочка событий, последовавшая за саммитом БРИКС, - крушение малазийского Боинга, жесткая риторика США с требованиями изоляции России, секторальные санкции против Москвы, мировые коммуникативные санкции - выделяется достаточно плотным совпадением: острый политический кризис, охвативший в 20132014 гг. Украину, вызвал колоссальный по своим масштабам резонанс в мире. Реакция на события, происходящие в Украине, последовала со стороны практически всех крупных стран мира, в том числе и Китая.

Череда военных столкновений на рубеже третьего тысячелетия, в которых активно применялись указанные технологии (Югославия, Афганистан, Сирия, Украина), со всей очевидностью показала, что использование интернета и нарождающихся «новых медиа» способно поменять характер, скорость и содержание (и даже направленность, меняя местами агрессора и защитника) социальных, в том числе политических и военных процессов, вооруженной борьбы, все активнее смещая их в сторону неконтактных методов ведения боевых действий в пользу более сильного в информационном и экономическом отношении противника. Одним из способов деструктивного применения новых информационных технологий является военная информационно-коммуникативная операция (ВИКО) ${ }^{7}$ «социальное пространство современного общества все более обретает свойства коммуницируемости, что в практическом плане открывает с одной стороны все новые информационные возможности для человека, но с другой создает все более изощренные механизмы информационно-деструктивного воздействия, к числу которых относятся и военные информационно-коммуникативные операции» ${ }^{8}$.

\footnotetext{
${ }^{7}$ Кафтан В.В., Щербина Д.Н. Военная информационно-ком муникативная операция в информационном пространстве современного общества // Пространство и Время. - 2013.

- №4 (14). - C. 224-230.

${ }^{8}$ Там же. С. 225.
}

А.В. Манойло, разграничивая понятия «информационная война» (далее - ИВ) и «информационное противоборство» (далее - ИП), утверждает, что «к информационному противоборству можно отнести любые формы социальной и политической конкуренции, в которых для достижения конкурентного преимущества предпочтение отдается средствам и способам информационно-психологического воздействия. Видно, что понятие информационного противоборства включает в себя весь спектр конфликтных ситуаций в информационно-психологической сфере - от межличностных конфликтов до открытого противостояния социальных систем. Информационно-психологическая война - это, безусловно, также один из видов информационного противоборства» ${ }^{9}$.ИВ также определяется исследователями как всеобъемлющая, целостная коммуникативная стратегия, основанная на использовании искаженной или вымышленной информации, которая является одним из способов ведения конфликта ${ }^{10}$. В основе информационно-психологической войны лежит определенная подача информации (еезапрещение, искажение, фальсификация) и намеренное скрытое воздействие.

Массированное информационное воздействие в ходе ведения боевых действий не является чемто принципиально новым. Китайские правители руководствуются традиционными «азиатскими ценностями»; достаточно вспомнить высказывание Сунь Цзы 25 веков назад: «сражаться и побеждать в каждой битве - это не высшее совершенство; высшее искусство состоит в том, чтобы сломить сопротивление врага без сражения» ${ }^{11}$, а также 36 китайских стратагем, позволяющих без боя привести к нужным изменениям и поражению противника ${ }^{12}$. Основные принципы восточных единоборств не предполагают прямого столкновения: на конечном этапе борьбы, добавив

\footnotetext{
${ }^{9}$ Манойло А.В. Информационно-психологическая война: факторы, определяющие формат современного вооруженного конфликта. [Электронный ресурс]. - URL: http:// psyfactor.org/lib/psywar35.htm (дата обращения 28.07.2014).

${ }^{10}$ Почепцов Г.Г. Информационные войны. - М.: Рефл-бук; Киев: Ваклер, 2000.

${ }^{11}$ Sun Tzu. The Art of War. Translated from Chunese by L. Giles. - MA., 1910.

${ }^{12}$ Нишанбаев Ю. Восточные стратагемы: библия стратега. - М.: Амита-Русь, 2009.
} 


\section{Тренды и управление 3(7) • 2014}

к чужой силе свою силу, необходимо вывернуть вектор силы противника в выгодную сторону. В общении с китайцами необходимо понимать код общения, т.е. не то, что говорится, а то, что подразумевается, не то, что на виду, а то, что скрыто, надо уметь раскодировать слова и поступки. Специфика китайского менталитета - в поиске некой третьей силы (неважно посредника или даже конкурента) на пути к цели: таким образом можно увести контрсилу в безопасное для них направление и только так можно сдвинуть нечто уже сложившееся с мертвой точки и начать другой сценарий. Не случайно на сегодняшний день Китай и США являются главными конкурирующими разработчиками теории и практики проведения ИП. За последнее десятилетие в Китае также отмечается быстрый рост публикаций на тему ИП и внешнеполитической пропаганды, но важным этапом в развитии китайской концепции стратегической коммуникации (далее - СК) следует считать выход в свет осенью 2011 г. первой китайской монографии по $\mathrm{CK}^{13}$. Среди работ китайских авторов, изучающих проблемы взаимоотношений с Поднебесной можно выделить двухтомник Луй Ижаня «История границ современного Китая» (2007), а также монографии Лоу Янляна «Геополитика и стратегия национальной безопасности Китая» (2002) и Цинь Яцина «Международная система и дипломатия Китая» ${ }^{14}$. В России гражданином КНР защищена диссертация по информационной политике руководства КНР ${ }^{15}$, в которой подчеркивается, что «исследование роли СМИ в формировании нового политического дискурса в трансформационном Китае, рассмотрение массмедийного обеспечения политики китайского правительства, анализ специфики информационного пространства КНР приобретают особую социально-политическую

13 毕研韬, 王金玲煮. 战略传播纲要

[Программа стратегической коммуникации]. - -

北京: 国 家行政学院出版社, 2011.-118 页。

${ }^{14}$ 吕一燃. 中国近代边界史 [История границ современного Китая]._-四川: 四川人民出版社, 2007 年; 罗耀亮. 地缘政治学中国国防战略. -一天津: 天津人民出版社 2002年; 秦亚青 等著. 国际体系与中国外交 [Международные системы и дипломатия Китая ]. - - 北京: 世界知识出版社 2009 年。

${ }^{15}$ У Сюцзюань. Информационное обеспечение политики китайского руководства на рубеже XX-XXI вв. Автореф. дис. ...канд. полит. наук. - М., 2010. актуальность». Из американских работ представляют определенный интерес исследования Ф. Бергстен, М. Б. Олкотт ${ }^{16}$.

Что касается российской практики, то «... специалисты признают, что в военном конфликте 2008 г. Россия потерпела информационное поражение, несмотря на эффективность физических методов ведения войны $»^{17}$. Однако во время южноосетинско-грузинского конфликта были выработаны некоторые успешные средства защиты, к которым, в частности, относятся приемы речевой стратегии аргументации, имеющей практически нулевойуровень конфликтности и направленной на объективный анализ проблем» ${ }^{18}$. ИВ по украинскому сценарию 2013-2014 гг. присуще перемещение акцентов с печатных СМИ к телевидению и далее к интернету, сетевым технологиям как факторам более мощного управления общественным мнением, которые медиаэксперты относят к «новейшим информационным технологиям» ${ }^{19}$, что еще более опасно, т.к. «сетевой принцип организации протестного движения напоминает принцип организации глобальных террористических сетей - по сути, это одна организационная технология» ${ }^{20}$. «Именно коммуникационное сопровождение террористической деятельности и распространение террористической идеологии часто на-

${ }^{16}$ Ф. Бергстен, Б. Гилл и др. Китай. Что следует знать о новой сверхдержаве. - М.: Институт комплексных стратегических исследований, 2007; Olcott M.B. Central Asia`s New States: Independence, Foreign Policy and Regional Security. - Wash., 1997.

17 Шатило Я.С., Шорин И.Ю. Психологические аспекты информационной войны // Информационная безопасность регионов. - Саратов, 2008. - №1. - С. 18-23.

${ }^{18}$ Ковалева Т. С. Стратегия манипуляции в информационной войне (на материале текстов Иносми, посвященных Южноосетинскому/Грузинскому конфликту 2008 г.). - Политическая лингвистика. - 3 (37). - 2011. - С. 86.

19 Добросклонская Т.Г. Язык средств массовой информации. - М.: КДУ, 2012; Землянова Л.М. Зарубежная коммуникативистика в преддверии информационного противоборства. - М., 1999; Виноградова Е.А. Ливия и страны Латинской Америки: информационное противоборство с Западом // Глобальные проблемы и международные отношения. - 2012. - №1. - С. 53- 58.

${ }^{20}$ Манойло А.В. Цветные революции и технологии демонтажа политических режимов // // NB: Международные отношения. - 2015. - №1. - C.1-19. DOI: 10.7256/23064226.2015.1.12614. [Электронный ресурс]. - URL: http:// e-notabene.ru/wi/article_12614.html (дата обращения 28.07.2014). 
прямую приводит к угрозам международной безопасности» ${ }^{21}$.

В данном контексте лингвосемиотическая система и/или политический дискурс СМИ КНР становятся экономическим и политическим фактором международных отношений. Поэтому изучение языка СМИ невозможно в отрыве от политических событий, политической коммуникации, к которой также относят язык СМИ. Политический дискурс как дискурс институциональный позволяет навязывать определенное мировоззрение посредством СМИ, поэтому журналистский текст или медиатекст в нашем случае выступает предметом и единицей анализа. В России вопросам медиадискурса и политического дискурса посвящены работы А.Н. Баранова ${ }^{22}$, Т.Г. Добросклонской ${ }^{23}$, А.Н. Алексахина ${ }^{24}$, О.Н. Морозовой, А.П. Чудинова ${ }^{25}$, Э.В. Будаева, Н.С. Рядовой ${ }^{26}$ и др.

Политическая лингвистика и медиалингвистика как междисциплинарные отрасли с ярко выраженным интегративным характером и своей методологией позволяют проводить исследования, цель которых заключается в целостном анализе формирования Китаем политик в отношении России и в отношении других стран с применением дискурсивного подхода, с последующей реакцией на возможное совершение Китаем и другими

\footnotetext{
${ }^{21}$ Базаркина Д.Ю. Угроза терроризма в современном мире: коммуникационный аспект // [Электронный ресурс]. URL: http://mic.org.ru/3-nomer-2012/128-ugroza-terrorizmav-sovremennom-mire-kommunikatsionnyj-aspekt (дата обращения 28.07.2014).

${ }^{22}$ Баранов А. Н. Лингвистическая экспертиза текста: теоретические основания и практика. - М.: ФЛИНТА, Наука, 2011.

23 Добросклонская Т.Г. Язык средств массовой информации. - М.: КДУ, 2012; Добросклонская Т. Г. Лингвистические способы выражения идеологической модальности в медиатекстах // Вестн. Моск. ун-та. Сер.19: Лингвистика и межкультурная коммуникация. - 2009. - №2. - С. 85-94.

${ }^{24}$ Алексахин А.Н. Преемственность и инновации в современном политическом дискурсе КНР. [Электронный pecypc]. - URL: http://www.risa.ru/images/8theses/s13aleksakhin.docx (дата обращения 03.06.2014).

25 Чудинов А.П. Политическая лингвистика. - М.: Флинта: Наука, 2012.

${ }^{26}$ Рядовая Н. С. Сопоставительный анализ аргументативных стратегий политического дискурса в кризисной ситу ации (на материале речей президентов в США и России): Автореф. дисс. ...канд. филол. наук. - Москва, 2013.
}

государствами действий во внешней политике, затрагивающих российские интересы.

Оценка современного состояния политической лингвистики или лингвополитологии в России позволяет выделить три подходак трактовке понятия «политический дискурс»: Е. И. Шейгал рассматривает политический дискурс как текущую речевую деятельность в определенном социальном пространстве, а также возникающие в результате данной деятельности произведения (тексты), рассматриваемые во взаимодействии лингвистических, паралингвистических и экстралингвистических факторов ${ }^{27}$. По В. Н. Базылеву политический дискурс является вербализацией измененного состояния сознания продуцента, которое выявляется при сопоставлении его с обыденным состоянием сознания, рассматриваемым как норма. Кроме того, по мнению ученого, политический дискурс способствует «раздвоению» социальной реальности на реальную инстанцию и ее образ, завуалированный и неясный ${ }^{28}$. B.3. Демьянков, интерпретируя политический дискурс в его целостности, говорит о том, что «нельзя ограничиваться чисто языковыми моментами, иначе суть и цель политического дискурса пройдут незамеченными. Понимание политического дискурса предполагает знание фона, ожиданий автора и аудитории, скрытых мотивов, сюжетных схем и излюбленных логических переходов, бытующих в конкретную эпоху» ${ }^{29}$.

Итак, политический дискурс может анализироваться как языковое выражение определенной общественно-политической практики, за которой стоит социально, исторически и идеологически обусловленная ментальность. Приоритетным методологическим ключом такого рода исследований выступают дискурс-анализ (анализ макросемантический и одновременно глубинно-семантичес-

\footnotetext{
${ }^{27}$ Шейгал Е.И. Семиотика политического дискурса. - Волгоград, 2000.

${ }^{28}$ Базылев В.Н. К изучению политического дискурса в России и российского политического дискурса // Политический дискурс в России-2: материалы рабочего совещания. - М., 1998.

29 Демьянков В.3. Политический дискурс как предмет политологической филологии. - Политическая наука. Политический дискурс: История и современные исследования. - №3. - М., 2002. - С.32-43.
} 


\section{Тренды и управление 3(7) • 2014}

кий $)^{30}$, методики компонентного и переводческого анализа со сравнительно-культурологическим описанием, а также когнитивное моделирование информационного пространства с привлечением методологии лингвосоциокультурного анализа журналистских текстов ${ }^{31}$. Исследования концептов, метафор и других аспектов политического дискурса, а также языка политического дискурса приобретают особую актуальность в современной геополитической ситуации. Как правило, исследования языка СМИ и журналистских текстов проводятся в перспективе дискурс-анализа. Дискурсивное направление представлено двумя вариантами: критический дискурс-анализ (сокращенно КДА) и дескриптивный дискурс-анализ ${ }^{32}$. Задачей КДА является выявление примеров взаимного влияния языка и социального устройства. Важным аспектом выступает критический взгляд на социальные явления, выраженные политической установкой. «Детальное изучение текстов помогает выявить имплицитно выраженные бессознательные установки коммуникантов и на этой основе показать результаты воздействия дискурса на восприятие информации.... Внимание специалистов по критическому дискурс-анализу особенно привлекают отрицательные образы «чужих» как представителей иных рас, этносов и культур. Под «чужими» подразумеваются как другие геополитические субъекты, так и международные отношения»33. Ведущими представителями КДА являются Норман Фэркло (Norman Fairclough), Рут Водак (Ruth Wodak), Тьон A. ван Дейк (Teun A. Van Dijk) и др.

Исследователи-китаеведы указывают на «наслоение» политического дискурса и традиционного дискурса КНР медиатекстов, что обуславливает определенную специфику перевода, интерпретации и восприятия информации. Существуют «моменты» (термин У. И. Берзиня), которые невозможно передать при переводе на язык западных культур именно в силу культуроспецифической

\footnotetext{
30 Чернявская В.Е. Лингвистика текста. Лингвистика дискурса. - М.: ЛЕНАНД, 2014. - С. 140-146.

${ }^{31}$ Богуславская В.В. Моделирование текста: лингвосоциокультурная концепция. Анализ журналистских текстов. - М.: Изд-во ЛКИ, 2013.

${ }^{32}$ Будаев Э.В., А.П. Чудинов. Зарубежная политическая лингвистика. - М.: Флинта: Наука, 2008.

${ }^{33}$ Там же. С. 55-57.
}

лексики или прецедентных феноменов китайского лингвокультурного общества. При переводе это приводит к трансформациям таких единиц, необходимости прибегать к компенсациям другими средствами языка, деметафоризации и зачастую к «потерям» чисто китайских «моментов», что ведет к выхолащиванию глубинного содержания.

Китайский политический дискурс ясно показывает творческую идейную борьбу правящей партии Китая - КПК за удержание политической власти в национальных интересах этой страны. Современная словесная формула политического дискурса КНР: «Цель Китая в XXI веке - осуществление «сяокан» ("小康"). Слово «сяокан» заимствуется из конфуцианского представления об идеальном обществе «датун», термин же «сяокан» обозначает предшествующую стадию идеального общества. Таким образом, в политическом дискурсе Китая происходит состыковка слов «шэхуйчжуи» (социализм) и «сяокан» ${ }^{34}$. Это совпадает с утверждением У.И. Берзиня о том, что «в терминах политической науки возможно описать явление, которое хорошо известно китаеведам, но далеко не очевидно политологам. А именно то, что создаваемые для китайцев современные политические тексты КНР не всегда совпадают в лексическом и смысловом плане со своими переводами, то есть, с теми же текстами, но предназначенными для внешнего пользователя» ${ }^{35}$. Для китайского политического дискурса СМИ характерны интертекстуальность и интердискурсивность. Под интердискурсивностью в КДА понимается внутренняя неоднородность текста, являющаяся результатом особой стилистики, жанра или дискурсивной практики» ${ }^{36}$.

Обратимся к примерам. Новостные тексты отобраны в качестве базовых медиатекстов исследования. В российском медийном пространстве аналитические статьи китайских интернет-изда-

\footnotetext{
${ }^{34}$ Алексахин А.Н. Преемственность и инновации в современном политическом дискурсе КНР. [Электронный pecypc]. - URL: http://www.risa.ru/images/8theses/s13aleksakhin.docx (дата обращения 30.06.2014).

${ }^{35}$ Берзиня У.А. Традиционный китайский дискурс в современном политическом дискурсе КНР (постановка проблемы). [Электронный ресурc]. - URL: http://www.synologia. ru/a/Традиционный_китайский_дискурс_(дата обращения: 18.03.2014)

${ }^{36}$ Fairclough N. Critical Discourse Analysis. - London. 1995. - P.218.
} 
ний с упоминанием Украины, В.В. Путина, российско-украинского кризиса, рекомендованные для «внутреннего» - китайского читателя - заблокированы. Значение новостных текстов велико благодаря их высокой повторяемости и воспроизводимости. Материалом для анализа послужили тексты, опубликованные в пик украинского кризиса, опубликованные 17-30 июля 2014 г. на различных китайских сайтах и интернет-изданиях средств массовой информации КНР. Оформление таких текстов в Интернете обусловлено особенностями компьютерных технологий и отличается высокой степенью организации материала и тщательно выстроенными межтекстовыми связями. Развертывание материала обычно происходит от общего к частному.

Одной из сильных при реализации стратегии манипуляции является мифологема-текст, в основе которой находится прецедентный текст как определенная вербальная единица - мифоноситель. Мифологема-текст наиболее близка к классическому пониманию мифа как «сказания» (от греч. mythos) и соответствует мифу-нарративу, т.е. сюжетно развернутому повествованию, обладающему элементами легенды, предания, сказки ${ }^{37}$. Так 18 июля в разделе “新 闻” («Новости») на китайском центральном канале CCTV, падение малазийского Боинга было представлено как коллигация действий, связанных друг с другом и имеющих одну центральную тему: в истории сбитых гражданских самолетов Россия «засветилась» больше других и идет отсылка к корейскому Боингу 1983 г., что объясняет, в том числе и инцидент лета 2014 г. как один из элементов.

В следующем случае речь пойдет об особенностях политического дискурса по поводу имиджа России в мире на примере анализ статьи “俄罗斯形象调查越来越不受世界欢迎 " 38 [ Образ России - все менее и менее привлекательный в мире»]. Для данной статьи характерны стратегия ссылки на эмоции, стратегия осуждения, стратегия обвинения, стратегия положительной самопрезентации и стратегия прогноза. Используется такой прием речевого воздействия, как «навязывание пресуппозиции», т.е.

\footnotetext{
${ }^{37}$ Шейгал Е.И. Семиотика политического дискурса.

- Волгоград, 2000. - С. 187.

${ }^{38} \mathrm{http}: / /$ club.kdnet.net/dispbbs.asp?boardid=1\&id=10227932
}

семантическая информация, важная для адресанта, подается не как новое знание, а как уже известное или как условие осмысленности сказанного. Достаточно полно вышеперечисленные стратегии и приемы демонстрирует выводной абзац статьи: “虽然到现在为此, 肇事方还没有确认， 但是来自国际社会的责难都纷纷指向 了俄罗斯。俄罗斯的国际形象也面 临着多年来最严重的下滑。…对俄罗斯 的负面情绪在美国和欧洲最为严重，超 过 $70 \%$ 的美欧民众对俄罗斯持负面看法 然而中国在其中恶得尤为特殊。绝大 多数中国受访者 $66 \%$ 表示了对俄罗 斯的喜爱, 高于这一比例的仅有俄罗斯 $92 \%$ 和越南 75\%”。-Перевод: «Несмотря на то, что ответственная сторона официально не подтверждена и не определена, Россия все же получит осуждение международного сообщества. Имидж России и так за последние годы сильно упал... Наиболее серьезные негативное отнотение к России в США и Европе: более $70 \%$ респондентов испытывают отрицательное отнотение к ней. ... Однако Китай стоит несколько особняком: 66\% респондентов проявляют симпатии к России; выше только в самой России (92\%) и Вьетнаме (75\%).

Следующая тема - санкции. Мифы-нарративы об отношениях между Россией и западными странами могут также заключать в себе элементы сказки, в которой страны - участницы конфликта представлены как жертва, злой герой (Россия), герой-освободитель (США), добрые помощники (Латвия с Литвой, Польша) и т.д. в зависимости от политики КПК.

В статье с заголовком“美欧多国打算 对俄罗斯实施新的制裁, ${ }^{39}$ [СШАиЕвро-пейские страны намерены ввести новые санкции в отношении России] эксплицитно представлена позиция западных держав по отношении к России без оценок со стороны китайской стороны: “

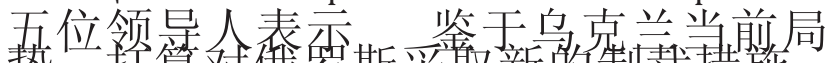
势, 打算对俄罗斯采取新的制裁措施。 公报说，鸟克兰杀部的冲突仍在继续， 五位领导人再次强调了为岛克兰 危机找到政治解决方式的重要性。 五位领导人议为，尽管多次向俄罗斯总 统普京发出呼吁,

俄罗斯㣙没有向乌克兰东部民间武装 施加压力以促使他们进行谈判,

${ }^{39}$ http://world.huanqiu.com/article/2014-07/5087555.html 


\section{Тренды и управление 3(7) • 2014}

也没有采取具体措施管控俄罗斯 与号克兰边境以

防止武器流入乌克兰境内”。-Перевод: 《B связи со сложившейся ситуацией на Украине пятерка лидеров заявила, что намерена принять новые санкции против России. В заявлении говорится, что конфликт по-прежнему продолжается на востоке Украины; пятерка лидеров в очередной раз подчеркнула важность политического решения по кризису на Украине. Несмотря на неоднократные призывы к президенту России Владимиру Путину, Россия по-прежнему не оказывает давления на боевиков в восточной части Украины с иелью призвать их к переговорам, и не принимает конкретных мер по контролю и предотвращеению поставок оружия через российско-украинскую гранииу». В данной статье китайский журналист констатирует события и отношения со ссылкой на позиции западных стран. В результате такого, казалось бы, нейтральной подачи событий в сознании китайского читателя Россия представляется государством, составляющим оппозицию всему миру с его демократическими ценностями. При этом осуществляется метонимический перенос: общечеловеческие ценности и мирное сосуществование выбирает Запад как представитель всего мирового сообщества, получая право выражать свою позицию как позицию всего мира и инициировать различного рода «воспитательные»и экономические санкции.

Таким образом, упрощается манипулятивное воздействие дискурса политических медиатекстов, так как автору дискурса достаточно убедить читателя склониться к одному из полюсов, и другой уже будет рассматриваться как враждебный.

Важной стратегией презентации выступает номинация. Анализ материалов интернет-изданий позволил выделить номинации, которые декларируются через китайские медиатексты. “普京 - 无人可以替代” - «Путин-незаменимый, “强权的普京主义” - «усиливающийся путинизм». Имеется тенденция к расширению номинаций за счет позиционирования себя по отношению к другим государствам.

Так, лингвистическое знание приобретают свою актуальность как инструмент прикладных политологических исследований. Реализация инструментальных функций лингвистического знания в экспертных исследовательских проектах является весьма эффективной.

Политический язык китайских медиа, доступных для просмотра, чтения и анализа на территории РФ, не позволяет обнаружить прямых информационно-психологических нападок на Россию и проводимую ею политику. Не выявлено слов-ярлыков, которые, как правило, присутствуют в условиях политического накала, медийные тексты характеризуются низким уровнем метафоризации, что объясняется стремлением китайских авторов, блогеров и журналистов к нейтральной оценке событий в России.

Однако следует отметить, что за мировыми экономическими санкциями против России остались малозаметными совсем другие - мировые коммуникативные санкции. В последние недели в связи с крушением самолета МН17 происходит исключение России из мирового коммуникативного пространства.

Курс на расширение своего влияния в регионе и мире Китай прокладывает осмотрительно. Дипломатия КНР стремится избежать конкуренци и с Россией: ШОС и БРИКС - средства сохранить статус-кво и не допустить перехода к «жесткой конкуренции». Китай непреклонен в отстаивании принципа невмешательства стран во внутренние дела друг друга: этот принцип лежит в основе всей внешнеполитической деятельности КНР. Россия испытывает естественную потребность в поддержании стабильных и эффективных политических, экономических и культурных отношений с Китаем, крупнейшим и географически близким к России союзом государств. Особым фактором, определяющим интенсивность взаимодействия России с КНР, является украинский кризис 2013-2014 гг., встреча руководителей стран-участниц БРИКС, создание нового банка и, как следствие, новый насыщенный уровень отношений. Взаимодействие КНР и РФ в области безопасности проявляется в близости понимания многих международных проблем, отсутствии устремлений создать какой бы то ни было блок, взаимном уважении интересов друг друга. 


\section{Библиография}

1. Алексахин А.Н. Преемственность и инновации в современном политическом дискурсе КНР. [Электронный ресурc]. - URL: http://www.risa.ru/images/8theses/s13-aleksakhin.docx

2. Базылев В.Н. К изучению политического дискурса в России и российского политического дискурса // Политический дискурс в России-2: материалы рабочего совещания. М. 1998.

3. Баранов А.Н. Лингвистическая экспертиза текста: теоретические основания и практика: учеб. пособие. Изд. 3-е. М.: Флинта: Наука, 2011.

4. Берзиня У.А. Традиционный китайский дискурс в современном политическом дискурсе КНР (постановка проблемы). [Электронный ресурc]. - URL: http://www.synologia.ru/a/Традиционный_китайский_дискурс_(дата обращения: 18.03.2014).

5. Богуславская В.В. Моделирование текста: лингвосоциокультурная концепция. Анализ журналистских текстов. М.: Изд-во ЛКИ, 2013.

6. БРИКС - Латинская Америка: позиционирование и взаимодействие (под. общ. ред. В. М. Давыдова). - М.: ИЛА РАН, 2014.

7. Будаев Э.В., А.П. Чудинов. Зарубежная политическая лингвистика: учеб. пособие. М.: Флинта: Наука, 2008.

8. Демьянков В.3. Политический дискурс как предмет политологической филологии. Политическая наука. Политический дискурс: История и современные исследования. №3. М., 2002. С.32-43.

9. Добросклонская Т.Г. Язык средств массовой информации: учеб. пособие. М.: КдУ, 2012.

10. Екшембеева Л.В. Прикладные исследования в контексте новых качеств лингвистического знания. [Электронный ресурc]. - URL: http://gisap.eu/ru/node/28927.

11. Карпович О. Г. Современные концепции управления международными конфликтами в миротворческих операциях: Автореф. дисс. ... докт. полит. наук. - М., 2012.

12. Кафтан В.В., Щербина Д.Н. Военная информационно-коммуникативная операция в информационном пространстве современного общества // Пространство и Время. 2013. №4 (14). С. 224-230.

13. Лукьянович Н. В. Геополитика. - М.:.Издательство Юрайт, 2014.

14. Манойло А.В. Информационно-психологическая война: факторы, определяющие формат современного вооруженного конфликта. [Электронный ресурc]. - URL: http://psyfactor.org/lib/psywar35.htm (дата обращения 28.07.2014).

15. Манойло А.В. Цветные революции и технологии демонтажа политических режимов // // NB: Международные отношения. - 2015. - №1. - C.1-19. DOI: 10.7256/2306-4226.2015.1.12614. [Электронный peсурс]. - URL: http://e-notabene.ru/wi/article_12614.html (дата обращения 28.07.2014).

16. Манойло А.В. Геополитические процессы в условиях «управляемого хаоса» // Геополитический журнал. - 2013. - №2. - С. 2-8.

17. Маслова В.А. Современные направления в лингвистике. М.: Изд. центр «Академия», 2008.

18. Ожиганов Э. Н. Моделирование и анализ политических процессов. - М.: РУДН, 2009.

19. Пихорович В. Д. Украина между Западом и Востоком: Хроники Евромайдана. - М.: ЛЕНАНД, 2014.

20. Современная политическая лингвистика: учеб. пособие / Э. В. Будаев, М. Б. Ворошилова, Е. В. Дзюба, Н А. Красильникова; отв. ред. А. П. Чудинов. Екатеринбург, Урал. гос. пед. ун-т, 2011.

21. Стариков Н. В. Геополитика: Как это делается. - Спб.: Питер, 2014.

22. Чернявская В.Е. Лингвистика текста. Лингвистика дискурса. М.: ЛЕНАНД, 2014.

23. Чудинов А.П. Политическая лингвистика: учеб. пособие. Изд. 4-е. М.: Флинта: Наука, 2012.

24. Шейгал Е.И. Семиотика политического дискурса. Волгоград, 2000.

25. Шпильная Н.В. Языковая картина мира в структуре речемыслительной деятельности языковой личности. - М.: Книжный дом «ЛИБРОКОМ», 2014.

26. У Сюцзюань. Информационное обеспечение политики китайского руководства на рубеже XX-XXI вв. Автореф. дис. ...канд. полит. наук. М., 2010. 


\section{Тренды и управление 3(7) • 2014}

27. Lobanova Tatiana N., Malyugina Natalia A. Discursive Nature of Chinese Mass Media Texts: Methodology and Methods of Research // Eastern European Scientific Journal: Düsseldorf (Germany): Auris Verlag, 2013.6. pp. 148-153.

28. Манойло А.В. Роль стратегий управляемого хаоса в формировании нового миропорядка // Право и политика. - 2014. - №5. - С. 638-651. DOI: 10.7256/1811-9018.2014.5.11816.

29. Манойло А.В. Управление международными конфликтами: соотношение интересов и ценностей. // Известия Саратовского университета. Новая серия. Серия Социология. Политология. 2013. № 4. C. 94-97.

30. Манойло А.В. Несиловое регулирование международных конфликтов. Культурно-цивилизационные парадигмы. // Космополис.-2008.-№2. - С.168-174.

31. Манойло А.В. Модели информационного воздействия на разрешение международных и внутриполитических конфликтов. // Федерализм.-2008.-№3. - С. 159-172.

32. Манойло А.В. Модель информационно-психологической операции в международных конфликтах. // Право и политика. 2008. №6. С.1387-1394.

33. Петренко А.И. Теоретические основы организации противодействия использованию арсенала сил, средств и методов информационно-психологической войны в политических целях // Тренды и управление. - 2014. - 2. - С. 154 - 167. DOI: 10.7256/2307-9118.2014.2.12412.

34. Гулиева Э.Ф. Политика Индии в БРИКС на современном этапе // Тренды и управление. - 2014. - 2. - С. 147 - 153. DOI: 10.7256/2307-9118.2014.2.12408.

35. Карпович О.Г. Современные концепции и модели управления международными конфликтами (сравнительный политологический анализ) // Национальная безопасность / nota bene. - 2013. - 4. - С. 605 - 612. DOI: 10.7256/2073-8560.2013.4.6434.

36. А. В. Манойло Парадигмы управления международным конфликтами: конкуренция или конфронтация // Национальная безопасность / nota bene. - 2011. - 5. - С. 135 - 142.

37. Шульц В.Л., Кульба В.В., Шелков А.Б., Чернов И.В. Сценарный анализ эффективности управления региональной безопасностью // Национальная безопасность / nota bene. - 2014. - 2. - С. 188 - 206. DOI: 10.7256/2073-8560.2014.2.11319.

38. Коробейников А.Г., Гришенцев А.Ю., Святкина М.Н. Применение интеллектуальных агентов магнитных измерений для мониторинга объектов железнодорожной инфраструктуры // NB: Кибернетика и программирование. - 2013. - 3. - С. 9 - 20. DOI: 10.7256/2306-4196.2013.3.8737. URL: http://www.enotabene.ru/kp/article_8737.html

39. Манойло А.В.Управление психологической войной // Международные отношения. - 2013. - 3. - С. 377 - 389. DOI: 10.7256/2305-560X.2013.3.6221.

40. В.В.Кульба, В.Л Шульц, А.Б Шелков, И.В.Чернов Методы и механизмы планирования и управления в условиях чрезвычайных ситуаций // Тренды и управление. - 2013. - 2. - C. 134 - 155. DOI: 10.7256/2307-9118.2013.2.8955.

41. А. А. Косоруков Основные детерминанты процесса принятия внешнеполитических решений // Национальная безопасность / nota bene. - 2012. - 4. - С. 29 - 46.

42. Чиронова И.И. Когнитивная структура концепта «Власть»в русскоязычном и англоязычном политических дискурсах // Право и политика. - 2013. - 12. - C. 1720 - 1730. DOI: 10.7256/1811-9018.2013.12.9542.

43. А.В. Манойло Технологии психологического воздействия на конфликты (на примере революций на Ближнем Востоке и в Северной Африке) // Психология и Психотехника. - 2011. - 5. - С. 73 - 80.

44. А.Г. Соколов Кризисный дискурс «Единой России» и КПРФ: сравнительный анализ // Национальная безопасность / nota bene. - 2013. - 2. - С. 217 - 226. DOI: 10.7256/2073-8560.2013.02.2.

45. О. Г. Карпович Современные подходы США и Европейского Союза к управлению международными конфликтами // Политика и Общество. - 2011. - 12. - С. 12 - 17. 


\section{References}

1. Aleksakhin A.N. Preemstvennost' i innovatsii v sovremennom politicheskom diskurse KNR. [Elektronnyi resurs]. - URL: http://www.risa.ru/images/8theses/s13-aleksakhin.docx

2. 2.Bazylev V.N. K izucheniyu politicheskogo diskursa v Rossii i rossiiskogo politicheskogo diskursa // Politicheskii diskurs v Rossii-2: materialy rabochego soveshchaniya. M. 1998.

3. 3.Baranov A.N. Lingvisticheskaya ekspertiza teksta: teoreticheskie osnovaniya i praktika: ucheb. posobie. Izd. 3-e. M.: Flinta: Nauka, 2011.

4. 4.Berzinya U.A. Traditsionnyi kitaiskii diskurs v sovremennom politicheskom diskurse KNR (postanovka problemy). [Elektronnyi resurs]. - URL: http://www.synologia.ru/a/Traditsionnyi_kitaiskii_diskurs_(data obrashcheniya: 18.03.2014).

5. 5.Boguslavskaya V.V. Modelirovanie teksta: lingvosotsiokul'turnaya kontseptsiya. Analiz zhurnalistskikh tekstov. M.: Izd-vo LKI, 2013.

6. 6.BRIKS - Latinskaya Amerika: pozitsionirovanie i vzaimodeistvie (pod. obshch. red. V. M. Davydova). - M.: ILA RAN, 2014.

7. 7.Budaev E.V., A.P. Chudinov. Zarubezhnaya politicheskaya lingvistika: ucheb. posobie. M.: Flinta: Nauka, 2008.

8. Dem'yankov V.Z. Politicheskii diskurs kak predmet politologicheskoi filologii. Politicheskaya nauka. Politicheskii diskurs: Istoriya i sovremennye issledovaniya. №3. M., 2002. S.32-43.

9. Dobrosklonskaya T.G. Yazyk sredstv massovoi informatsii: ucheb. posobie. M.: KDU, 2012.

10. Ekshembeeva L.V. Prikladnye issledovaniya v kontekste novykh kachestv lingvisticheskogo znaniya. [Elektronnyi resurs]. - URL: http://gisap.eu/ru/node/28927.

11. Karpovich O. G. Sovremennye kontseptsii upravleniya mezhdunarodnymi konfliktami v mirotvorcheskikh operatsiyakh: Avtoref. diss. ... dokt. polit. nauk. - M., 2012.

12. Kaftan V.V., Shcherbina D.N. Voennaya informatsionno-kommunikativnaya operatsiya v informatsionnom prostranstve sovremennogo obshchestva // Prostranstvo i Vremya. 2013. №4 (14). S. 224-230.

13. Luk'yanovich N. V. Geopolitika. - M.:.Izdatel'stvo Yurait, 2014.

14. Manoilo A.V. Informatsionno-psikhologicheskaya voina: faktory, opredelyayushchie format sovremennogo vooruzhennogo konflikta. [Elektronnyi resurs]. - URL: http://psyfactor.org/lib/psywar35.htm (data obrashcheniya 28.07.2014).

15. Manoilo A.V.Tsvetnye revolyutsii i tekhnologii demontazha politicheskikh rezhimov // // NB: Mezhdunarodnye otnosheniya. - 2015. - №1. - S.1-19. DOI: 10.7256/2306-4226.2015.1.12614. [Elektronnyi resurs]. - URL: http://e-notabene.ru/wi/article_12614.html (data obrashcheniya 28.07.2014).

16. Manoilo A.V. Geopoliticheskie protsessy v usloviyakh «upravlyaemogo khaosa» // Geopoliticheskii zhurnal. - 2013. - №2. - S. 2-8.

17. Maslova V.A. Sovremennye napravleniya v lingvistike. M.: Izd. tsentr «Akademiya», 2008.

18. zhiganov E. N. Modelirovanie i analiz politicheskikh protsessov. - M.: RUDN, 2009.

19. Pikhorovich V. D. Ukraina mezhdu Zapadom i Vostokom: Khroniki Evromaidana. - M.: LENAND, 2014.

20. Sovremennaya politicheskaya lingvistika: ucheb. posobie / E. V. Budaev, M. B. Voroshilova, E. V. Dzyuba, N A. Krasil'nikova; otv. red. A. P. Chudinov. Ekaterinburg, Ural. gos. ped. un-t, 2011.

21. Starikov N. V. Geopolitika: Kak eto delaetsya. - Spb.: Piter, 2014.

22. Chernyavskaya V.E. Lingvistika teksta. Lingvistika diskursa. M.: LENAND, 2014.

23. Chudinov A.P. Politicheskaya lingvistika: ucheb. posobie. Izd. 4-e. M.: Flinta: Nauka, 2012.

24. Sheigal E.I. Semiotika politicheskogo diskursa. Volgograd, 2000.

25. Shpil'naya N.V. Yazykovaya kartina mira v strukture rechemyslitel'noi deyatel'nosti yazykovoi lichnosti. - M.: Knizhnyi dom «LIBROKOM», 2014.

26. U Syutszyuan'. Informatsionnoe obespechenie politiki kitaiskogo rukovodstva na rubezhe XX-XXI vv. Avtoref. dis. ...kand. polit. nauk. M., 2010. 


\section{Тренды и управление 3(7) • 2014}

27. Lobanova Tatiana N., Malyugina Natalia A. Discursive Nature of Chinese Mass Media Texts: Methodology and Methods of Research // Eastern European Scientific Journal: Düsseldorf (Germany): Auris Verlag, 2013.6. pp. 148-153.

28. Manoilo A.V. Rol' strategii upravlyaemogo khaosa v formirovanii novogo miroporyadka // Pravo i politika. - 2014. - №5. - S. 638-651. DOI: 10.7256/1811-9018.2014.5.11816.

29. Manoilo A.V. Upravlenie mezhdunarodnymi konfliktami: sootnoshenie interesov i tsennostei. // Izvestiya Saratovskogo universiteta. Novaya seriya. Seriya Sotsiologiya. Politologiya. 2013. №4. S. 94-97.

30. Manoilo A.V. Nesilovoe regulirovanie mezhdunarodnykh konfliktov. Kul'turno-tsivilizatsionnye paradigmy. // Kosmopolis.-2008.-№2. - S.168-174.

31. Manoilo A.V. Modeli informatsionnogo vozdeistviya na razreshenie mezhdunarodnykh i vnutripoliticheskikh konfliktov. // Federalizm.-2008.-№3. - S. 159-172.

32. Manoilo A.V. Model' informatsionno-psikhologicheskoi operatsii v mezhdunarodnykh konfliktakh. // Pravo i politika. 2008. №6. S.1387-1394.

33. Petrenko A.I. Teoreticheskie osnovy organizatsii protivodeistviya ispol'zovaniyu arsenala sil, sredstv i metodov informatsionno-psikhologicheskoi voiny v politicheskikh tselyakh // Trendy i upravlenie. - 2014. - 2. - C. 154 - 167. DOI: 10.7256/2307-9118.2014.2.12412.

34. Gulieva E.F. Politika Indii v BRIKS na sovremennom etape // Trendy i upravlenie. - 2014. - 2. - C. 147 - 153. DOI: 10.7256/2307-9118.2014.2.12408.

35. Karpovich O.G. Sovremennye kontseptsii i modeli upravleniya mezhdunarodnymi konfliktami (sravnitel'nyi politologicheskii analiz) // Natsional'naya bezopasnost' / nota bene. - 2013. - 4. - C. 605 - 612. DOI: 10.7256/2073-8560.2013.4.6434.

36. A. V. Manoilo Paradigmy upravleniya mezhdunarodnym konfliktami: konkurentsiya ili konfrontatsiya // Natsional'naya bezopasnost' / nota bene. - 2011. - 5. - C. 135 - 142.

37. Shul'ts V.L., Kul'ba V.V., Shelkov A.B., Chernov I.V. Stsenarnyi analiz effektivnosti upravleniya regional'noi bezopasnost'yu // Natsional'naya bezopasnost' / nota bene. - 2014. - 2. - C. 188 - 206. DOI: 10.7256/2073-8560.2014.2.11319.

38. Korobeinikov A.G., Grishentsev A.Yu., Svyatkina M.N. Primenenie intellektual'nykh agentov magnitnykh izmerenii dlya monitoringa ob"'ektov zheleznodorozhnoi infrastruktury // NB: Kibernetika i programmirovanie. - 2013. - 3. - C. 9 - 20. DOI: 10.7256/2306-4196.2013.3.8737. URL: http://www.e-notabene. $\mathrm{ru} / \mathrm{kp} /$ article_8737.html

39. Manoilo A.V. Upravlenie psikhologicheskoi voinoi // Mezhdunarodnye otnosheniya. - 2013. - 3. - C. 377 - 389. DOI: 10.7256/2305-560X.2013.3.6221.

40. V.V.Kul'ba, V.L Shul'ts, A.B Shelkov, I.V.Chernov Metody i mekhanizmy planirovaniya i upravleniya v usloviyakh chrezvychainykh situatsii // Trendy i upravlenie. - 2013. - 2. - C. 134 - 155. DOI: 10.7256/2307-9118.2013.2.8955.

41. A. A. Kosorukov Osnovnye determinanty protsessa prinyatiya vneshnepoliticheskikh reshenii // Natsional'naya bezopasnost' / nota bene. - 2012. - 4. - C. 29 - 46.

42. Chironova I.I. Kognitivnaya struktura kontsepta «Vlast'» v russkoyazychnom i angloyazychnom politicheskikh diskursakh // Pravo i politika. - 2013. - 12. - C. 1720 - 1730. DOI: 10.7256/1811-9018.2013.12.9542.

43. A.V. Manoilo Tekhnologii psikhologicheskogo vozdeistviya na konflikty (na primere revolyutsii na Blizhnem Vostoke i v Severnoi Afrike) // Psikhologiya i Psikhotekhnika. - 2011. - 5. - C. 73 - 80.

44. A.G. Sokolov Krizisnyi diskurs «Edinoi Rossii» i KPRF: sravnitel'nyi analiz // Natsional'naya bezopasnost' / nota bene. - 2013. - 2. - C. 217 - 226. DOI: 10.7256/2073-8560.2013.02.2.

45. O. G. Karpovich Sovremennye podkhody SShA i Evropeiskogo Soyuza k upravleniyu mezhdunarodnymi konfliktami // Politika i Obshchestvo. - 2011. - 12. - C. 12 - 17. 